\title{
IN VITRO ASSESSMENT OF CYTOTOXICITY AND OXIDATIVE STRESS PARAMETERS OF NATURAL RUBBER LATEX MEMBRANES STABILIZED WITH DIFFERENT CONCENTRATIONS OF AMMONIA IN CHO-K1 CELLS
}

\author{
Caroline de Souza Araujo ${ }^{1}$, Dalita Gomes Silva Morais Cavalcante ${ }^{2}$, Nathália Oliveira Braga ${ }^{2}$, Andressa Silva \\ Gomes $^{2}$, Eidi Yoshihara ${ }^{3}$, Leandra Ernst Kerche ${ }^{1}$, Aldo Eloizo Job ${ }^{2}$ \\ ${ }^{1}$ Universidade do Oeste Paulista - UNOESTE, Presidente Prudente, SP; ${ }^{2}$ Universidade Estadual Paulista - UNESP, \\ Presidente Prudente, SP; ${ }^{3}$ Agência Paulista de Tecnologia dos Agronegócios - APTA, Presidente Prudente, SP. e-mail: \\ leakerche@unoeste.br
}

\begin{abstract}
The purpose of this study was to assess in vitro cytotoxicity of natural rubber (NR) latex membranes stabilized with different concentrations of ammonia, as well as evaluate possible changes in oxidative stress parameters. To this end, CHO-k1 cells were exposed to NR membranes for $24 \mathrm{~h}$. Cytotoxicity was assessed by the MTT assay and the oxidative stress parameters were established by glutathione (GSH) and malondialdehyde (MDA) levels. The results show that the ammonia present in the NR latex membranes can deplete cell viability and enhance GSH consumption in the cells. NR latex membranes stabilized with $2.0 \%$ of ammonia were cytotoxic to the cell lineage used in this study. From these results, it is possible to infer that the use of ammonia to stabilize NR latex membranes with biomedical purposes has to be done carefully, to avoid possible harmful effects to human health.
\end{abstract}

Keywords: Natural rubber latex, membranes, ammonia, cytotoxicity, GSH.

\section{AVALIAÇÃO IN VITRO DA CITOTOXICIDADE E PARÂMETROS DE ESTRESSE OXIDATIVO DE MEMBRANAS ESTABILIZADAS COM DIFERENTES CONCENTRAÇÕES DE AMÔNIA EM CÉLULAS CHO-K1}

\section{RESUMO}

O objetivo deste estudo foi avaliar in vitro a citotoxidade de membranas de borracha natural (BN) estabilizada com diferentes concentrações de amônia, assim como avaliar as possíveis modificações de parâmetros de estresse oxidativo. Para este fim, células CHO-k1 foram expostas a membranas de BN por 24 h. A citotoxicidade foi avaliada pelo ensaio do MTT e os parâmetros de estresse oxidativo foram estabelecidos pelos níveis de glutationa (GSH) e malondialdeído (MDA). Os resultados mostraram que a amônia, presente nas membranas de BN podem diminuir a viabilidade celular e aumentar o consumo de GSH nas células. As membranas de BN estabilizadas com 2,0\% de amônia foram citotóxicas para a linhagem celular utilizada neste estudo. A partir destes resultados, é possível inferir que o uso de amônia para estabilizar as membranas de BN com propósitos biomédicos devem ser feitas cuidadosamente, para evitar possíveis malefícios à saúde humana.

Palavras-chave: Látex de borracha natural, membranas, amônia, citotoxicidade, GSH.

\section{INTRODUCTION}

Natural rubber (NR) latex from Hevea brasiliensis is a colloidal anionic system formed by rubber particles stabilized in a shell of phospholipids and proteins ${ }^{1,2}$. Lately, NR membranes has been investigated as delivery system of proteins ${ }^{3}$, drugs ${ }^{4}$ and nanoparticles ${ }^{5,6}$. This material also is capable of enhancing soft tissue healing, being used in several medical applications like prosthetics and bone grafts ${ }^{1,7,8}$. 
Since fresh latex can spontaneously coagulate and putrefy shortly after it leaves the tree, ammonia is used to preserve NR and so it can be used as membranes. Ammonia solution in NR can inhibit bacteria action mainly because it elevates the $\mathrm{pH}$ conditions, hydrolyzes fatty acids esters and stabilizes the NR system ${ }^{9}$.

Although ammonia is used to preserve and stabilize NR latex, it is highly toxic since it can disturb the $\mathrm{pH}$ balance of the cytoplasm and body fluids ${ }^{10}$, modify the secretion of cytokines and elevate the activity of lysosomal hydrolases ${ }^{11}$. Besides this effects, ammonium ions inhibit important enzymes involved in protein metabolism, which can lead to free radical generation, and reduction of the antioxidant enzymes ${ }^{12}$.

Besides the NR latex membranes being implicated in several biomedical applications, only few studies in the literature evaluated ammonia associated with NR latex membranes toxicity ${ }^{13,14}$. Therefore, there is an urgent need to evaluate the use of ammonia as latex stabilizing agent for biomedical purposes: evaluation of possible harmful impacts that ammonia can cause to biological systems.

In vitro tests are important tools to assess biological responses to a certain material and to evaluate preliminary human health security ${ }^{15}$. These tests allow the analysis of potential cytotoxicity of a substance/material, and also allow the quantification of sublethal damages to biological systems, such as oxidative stress parameters $^{16}$.

Therefore, the aim of this study was to evaluate the cytotoxic potential of NR latex membranes stabilized with different concentrations of ammonia and to assess possible changes in oxidative parameters. These results are important to stablish safety incorporation of ammonia as stabilizing agent in NR latex membranes used for biomedical purposes.

\section{METHODOLOGY}

\section{Membrane preparation}

Natural rubber (NR) latex membranes were prepared using latex collected from rubber trees Hevea brasiliensis (RRIM 600 clone) in an experimental farm in Indiana City, in the region of Presidente Prudente, São Paulo State, Brazil. The latex was obtained by the tapping method and stored at a low temperature. Samples of latex were stabilized with $0.25 \%, 0.5 \%, 1.0 \%$, and $2.0 \%$ of ammonium hydroxide ( $\mathrm{v} / \mathrm{v})$. NR membranes were prepared by casting at temperature of $65^{\circ} \mathrm{C}$ and they were annealed for $10 \mathrm{~h}$. The NR membranes used in the cell toxicity tests were sterilized with ethylene oxide.

Qualitative chemical characterization of NR membranes using FTIR spectroscopy

For the chemical characterization of natural rubber membranes stabilized with different concentrations of ammonia, Fourier Transform Infrared (FTIR) technique was used. These spectra were compared with the spectrum observed for the natural rubber membrane without ammonia.

\section{Cell Line}

For the experiments, CHO-k1 (Chinese hamster ovary) cell line was cultured in $10 \mathrm{~mL}$ of DMEM-F10 (1:1) medium supplemented with $10 \%$ fetal bovine serum in $25 \mathrm{~cm}^{2}$ flasks and kept in an incubator with $5 \% \mathrm{CO}_{2}$ atmosphere at $37^{\circ} \mathrm{C}$.

\section{Cell Exposure Protocol}

In vitro evaluation of cytotoxic effects of the NR latex membranes stabilized with different concentrations of ammonia were carried out using extract dilution and direct contact method.

For extract dilution method, liquid extracts of the membranes NR ( $0 \%$ ammonia), $0.25 \%, 0.5 \%, 1.0 \%$ and $2.0 \%$ were obtained following ASTM F619 standards ${ }^{17}$. Briefly, the NR membranes samples were crushed into pieces, mixed with PBS (phosphate buffer saline $\mathrm{pH}$ 7.4) extraction solution at a ratio of $60 \mathrm{~cm}^{2} / 20 \mathrm{~mL}$, and maintained under these conditions for $24 \mathrm{~h}$ without agitation. Thereafter, the solid pieces of composite material were removed and the liquid extracts were filtered, $\mathrm{pH}$ adjusted to 7.4 with $\mathrm{NaOH}$, and used to perform biological assays. After the preparation of the extracts, the cells were cultured in 24-well plate with $200 \mu \mathrm{L}$ of culture medium and exposed to $200 \mu \mathrm{L}$ of the different extracts, using PBS as negative control (NC), for $24 \mathrm{~h}$.

For the direct contact method, ethylene oxide sterilized $100 \mathrm{~mm}^{2}$ square pieces of COF and NR latex membranes were used. The cell suspension was distributed in a 12 -well plate at 37 ㅇ $\mathrm{C}$ for the formation of the cell monolayer. Then fragments of the membranes or nontoxic filter fragments (NC) were placed on the center of the well plate in contact with the cells for a period of $24 \mathrm{~h}$. 
After the exposure period, the cytotoxic potential and biochemical parameters of oxidative stress were evaluated.

Evaluation of in vitro cytotoxicity

For cytotoxic potential, MTT reduction method was performed according to Mosmann ${ }^{17}$. Briefly, $0.3 \mathrm{mg} / \mathrm{mL}$ of MTT solution was added and cells were incubated at $37^{\circ} \mathrm{C}$ for an additional $4 \mathrm{~h}$. The absorbance of each sample was determined using a microplate reader at $492 \mathrm{~nm}$. The absorbance of the NC was considered to represent $100 \%$ of cell viability (CV). The CV of the other samples was determined using the following formula: $C V E=[(A E-A B) /(A C T R-A B)]$ $\times 100$, where CVE is the viability of cells exposed to the extract, $A E$ is the absorbance of the cells exposed to the different extracts, ACTR is the absorbance of cells exposed to PBS and AB is the absorbance of the blank (well containing a culture medium only).

\section{Measurement of glutathione (GSH) levels}

GSH levels were determined by addition of 5,5'-dithio-bis (2-nitrobenzoic acid) (DTNB), as described by Ellman ${ }^{18}$. DTNB, a symmetric aryl disulfide, reacts with free thiols to form disulfide and 2-nitro-5-thiobenzoic acid; the latter product can be quantified by its absorbance at $412 \mathrm{~nm}$. The measurements were conducted with a spectrophotomer (Quimis, São Paulo, Brazil) and concentration of total proteins was measured as described by Bradford ${ }^{19}$. Results are expressed as $\mathrm{nmol} / \mathrm{g}$ of protein.
Measurement of malondialdehyde (MDA) levels

MDA levels were determined by the addition of thiobarbituric acid (TBA), as described by Uchiyama and Mihara ${ }^{20}$, with modifications. Briefly, $200 \mu \mathrm{L}$ of cell homogenates were mixed with $400 \mu \mathrm{L}$ of the TBA solution (1\% TBA, $50 \mathrm{mM}$ $\mathrm{NaOH}$ and $0.1 \mathrm{mM} \mathrm{BHT}$ ) and $200 \mu \mathrm{L}$ of $7 \%$ phosphoric acid. The mixtures were incubated in a boiling bath for $15 \mathrm{~min}$. After cooling the tubes on ice, $1.5 \mathrm{~mL}$ of $\mathrm{n}$-butanol was added and the reaction mixture was centrifuged at $5000 \times \mathrm{g}$ for $10 \mathrm{~min}$. The absorbance of the supernatant was read at $532 \mathrm{~nm}$, and the concentrations of MDA were calculated using tetraethoxy propane as a reference standard.

\section{Statistical Analysis}

The results are shown as mean \pm SD. All testes were statistically significant at $95 \%$ of confidence level in Graph-Pad Prism ${ }^{\circ}$ 6.01. For cytotoxicity, comparisons between multiple groups were performed using One-way ANOVA with Dunnett. For biochemical parameters, comparisons between multiple groups were performed using One-Way ANOVA with Tukey.

\section{RESULTS}

Qualitative chemical characterization of NR membranes using FTIR spectroscopy

FTIR spectra showed a small band at 1562 $\mathrm{cm}^{-1}$ in all membranes stabilized with ammonia, indicating the formation of amide groups $\mathrm{R}$ $\mathrm{CONH}_{2}$. The results are shown in Figure 1. 


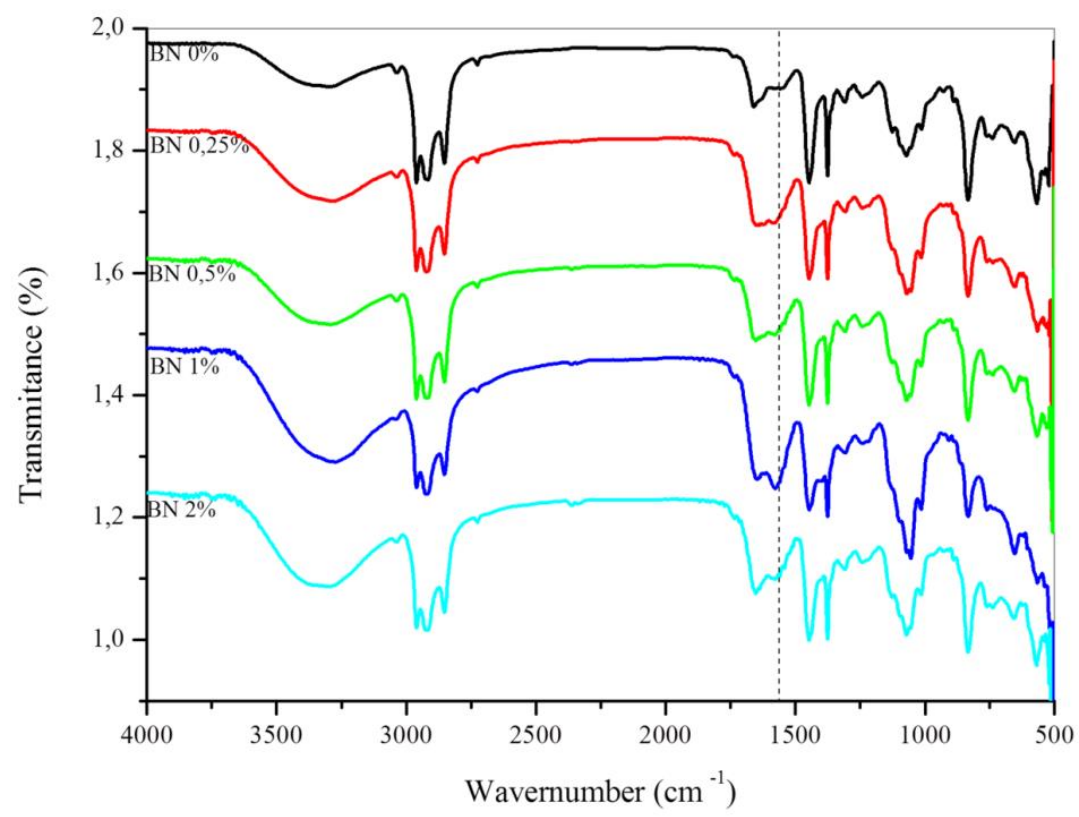

Figure 1. Absorbance spectra of NR membranes stabilized with different concentrations of ammonia.

Evaluation of in vitro cytotoxicity

Cytotoxicity evaluation was assessed by the MTT assay and the results are shown in Figure 2. In Figure $2 \mathrm{~A}$ is shown that that the extracts obtained from the membranes of NR alone and the membranes of NR stabilized with $0.25 \%, 0.5 \%, 1.0 \%$ and $2.0 \%$ of ammonia did not alter cell viability of $\mathrm{CHO}-\mathrm{k} 1$ cells after $24 \mathrm{~h}$ of exposure. In Figure 2B, the assessment of the cell viability from direct contact showed that membranes stabilized with $0.5 \%$ and $2.0 \%$ of ammonia differed statistically from the negative control (NC). The cells exposed to NR membranes with $0.5 \%$ of ammonia presented an increase in the cell viability while NR membranes with $2.0 \%$ of ammonia depleted cell viability. It is possible to infer from these results show that the presence of ammonia in the NR membranes can influence the metabolic activity of $\mathrm{CHO}-\mathrm{k} 1$ cells.

Measurement of glutathione (GSH) levels

It can be seen in Figure 3 that the different concentrations of ammonia caused significant reduction of the cellular levels of GSH in a dose dependent manner $(p \leq 0.05)$.

Measurement of malondialdehyde (MDA) levels

In Figure 4 it is possible to verify that the extracts of NR latex membranes with different concentrations of ammonia didn't raise significantly the levels of MDA in CHO-k1 cells.
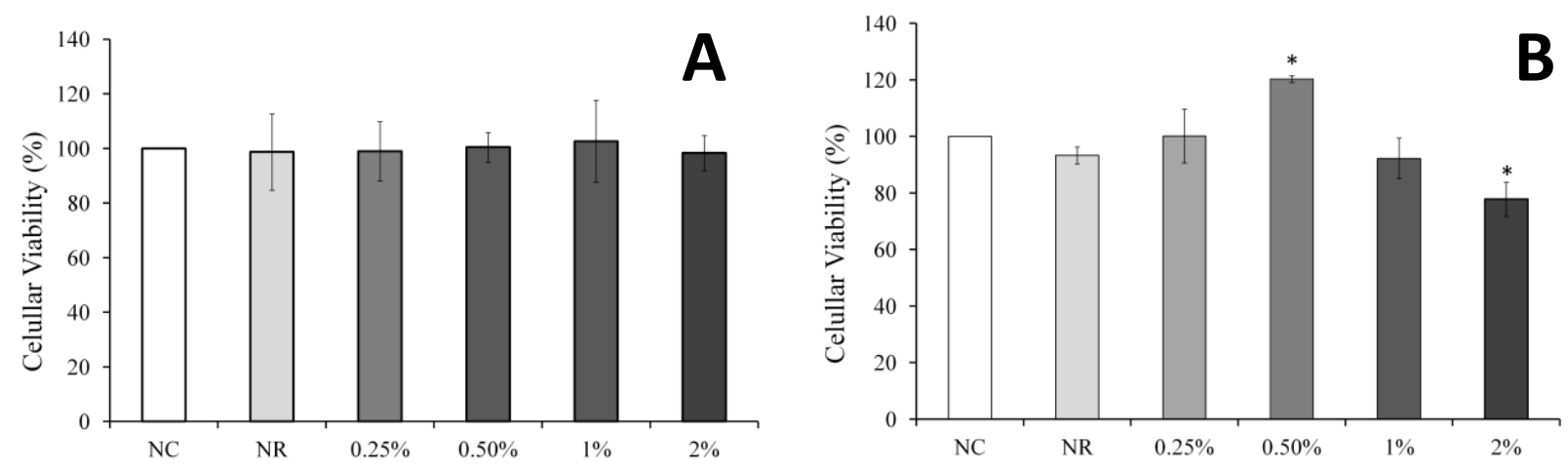

Figure 2. Impact of treatment of Natural Rubber membranes stabilized with $0.25 \%, 0.5 \%, 1.0 \%$ and $2.0 \%$ of ammonia on cell viability of CHO-k1 cells. (A) Cell viability of the extracts obtained from the membranes. (B) Cell viability assessment from direct contact to the membranes. Cell cultures were exposed for $24 \mathrm{~h}$. Bars represent means \pm SD of results. ${ }^{*}$ Indicate statistical difference between control group and treated cell groups. ANOVA and Dunnett's test $(p \leq 0.05)$. 


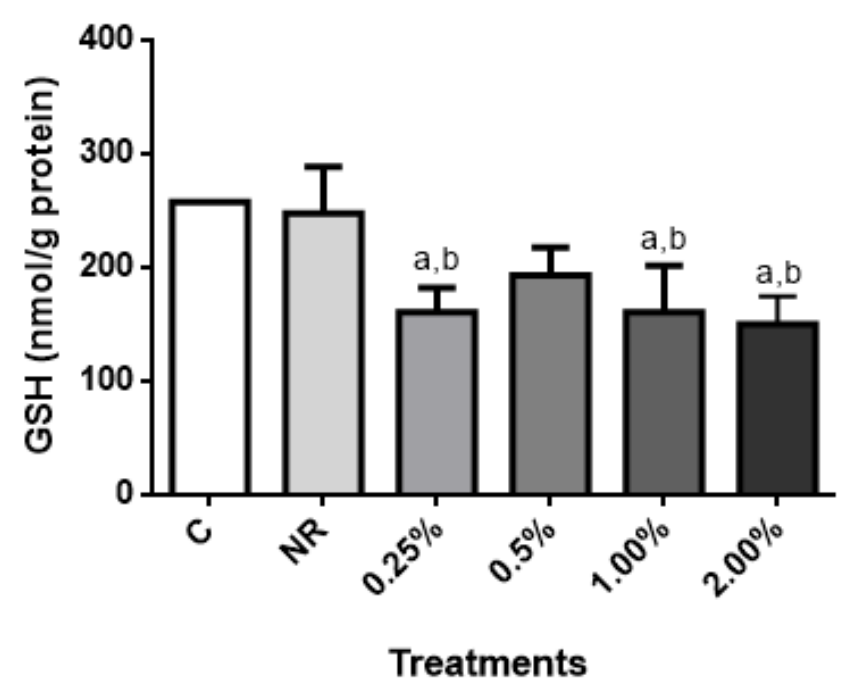

Figure 3 - Quantification of GSH in CHO-k1 cells after exposure to Natural Rubber membranes stabilized with $0.25 \%, 0.5 \%, 1.0 \%$ and $2.0 \%$ of ammonia. Cell cultures were exposed for $24 \mathrm{~h}$. Bars represent means \pm SD of results. ${ }^{a}$ Statistically different from control group (C) and ${ }^{b}$ statistically different from NR control group. ANOVA and Dunnett's test $(p \leq 0.05)$.

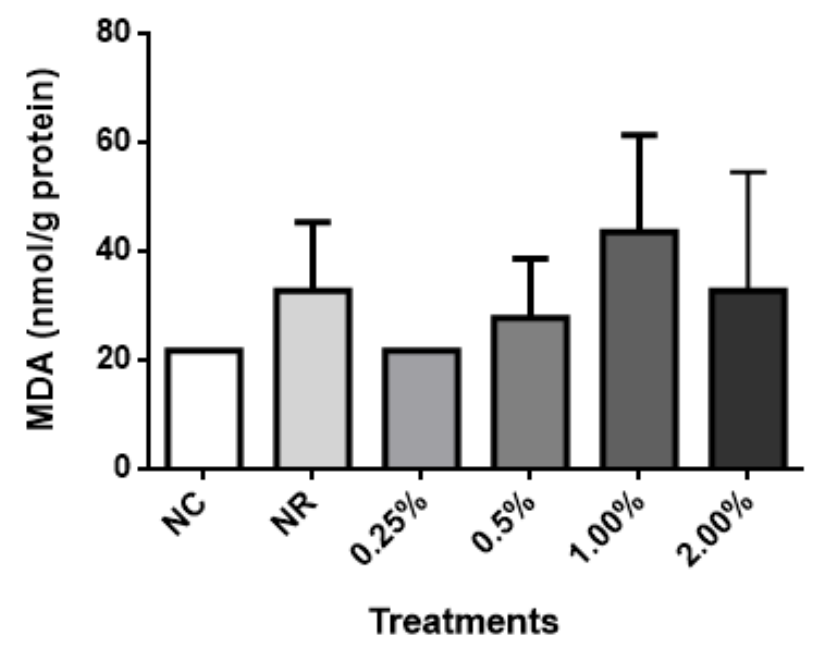

Figure 4 - Quantification of MDA in CHO-k1 cells after exposure to Natural Rubber membranes stabilized with $0.25 \%, 0.5 \%, 1.0 \%$ and $2.0 \%$ of ammonia. Cell cultures were exposed for $24 \mathrm{~h}$. Bars represent means \pm SD of results. ANOVA and Dunnett's test $(p \leq 0.05)$.

\section{DISCUSSION}

Natural rubber (NR) latex from Hevea brasiliensis is a raw material that after polymerization acquires important distinct characteristics at low costs such as elasticity, flexibility, and strength ${ }^{21-23}$. NR has been proven to be biocompatible, naturally stimulating angiogenesis as well as cell adhesion and extracellular matrix formation ${ }^{21,24,25}$.

But after extraction, NR can clot which makes the use of ammonia solutions common before its transformation into different kinds of products. Depending on the storage time, concentrations ranging from $0.2 \%$ to $2 \%$ are used for the preservation of latex. However, ammonia is considered an irritant substance and the use of NR latex membranes as biomaterial presents the concern of hypersensitivity reactions in the host.

Analyzing the FTIR spectra of natural rubber membranes it was possible to observe the appearance of a small band at $1562 \mathrm{~cm}^{-1}$ in all rubber membranes stabilized with different concentrations of ammonia, but this did not occur in the membrane without ammonia. This result corroborates to the results found by Floriano et al. ${ }^{23}$ that also viewed the appearance of the same band in rubber membranes stabilized with $2.0 \%$ ammonia. According to these authors, 
this band is linked to the reaction of ammonia with the membrane, leading to the formation of amide groups $\mathrm{R}-\mathrm{CONH}_{2}$.

The test used to assess cell viability in CHO-k1 cells was the MTT reduction assay that can evaluate indirectly the level of metabolic activity in eukaryotic cells ${ }^{26,27}$. Therefore, it is possible to verify that the ammonia presented at $0.5 \%$ in the NR membranes somehow interfered in the metabolism of the exposed cells, causing a higher reduction of the tetrazolium into formazan. This raise in the metabolism could be an adaptative cell response to a stressful change in the environment provoked by the presence of ammonia. Martinelle and Häggström ${ }^{28}$ showed that the presence of ammonia causes an enhance in the cell demand for energy, since the presence of ammonia can alter ions gradients in the cell membranes.

However, to the cells that were exposed to a higher amount of ammonia (2.0\%) it is possible to infer that the adaptive capacity of dealing with a stressful environment was saturated, causing the death of the cells ${ }^{29}$. Floriano et al. ${ }^{23}$ also found that NR membranes that were stabilized with $2.0 \%$ of ammonia at harvest are more cytotoxic that the NR membranes prepared without the ammonia. Corroborating with this data, our work also found that NR membranes stabilized with $2.0 \%$ of ammonia presented cytotoxic potential to the cell lineage used in this study.

In addition to the cytotoxic potential of the membranes, measurements of two biochemical parameters to monitor the redox status of the cells were performed. Lately, GSH has become an important factor of research activity due to its multiple roles in cell function and cell survival. Bobermin et al. ${ }^{30}$ demonstrated that ammonia treatment can decrease GSH content in rat neurons, indicating enhanced GSH consumption. GSH has also been indicated as supply counteract in ammonia-induced cell death $^{31}$. Our work, using CHO-k1 cells shows that different concentrations of ammonia associated with NR latex increased the consumption of GSH in these cells, especially the concentration of $2.0 \%$. One possible explanation for the depletion of intracellular GSH found in this study could be assigned to the use of the glutathione for obtainment of glutamate, the latter used in the cells to detoxify from ammonia ${ }^{32,33}$.

Another analyzed biochemical parameter was the formation of malondialdehyde (MDA), an indicative of lipoperoxidation. Although it can be seen an increase in the MDA levels of the cells treated with the extract of NR latex membrane and in the cells treated with the extract of NR latex stabilized with $1.0 \%$ of ammonia, it was not statistically significant. A slightly increase in MDA concentrations in the cells was also found by Davuluri et al. $^{34}$, that studied the effects of hyperammonemia in skeletal muscle. They verify that an elevation in the concentrations of ammonia in the cells increased mitochondrial matrix enzyme manganese dependent superoxide dismutase (MnSOD) expression, which provoked an increase in ROS and also in lipoperoxidation. This increase in the MnSOD could also be another explanation for the raise in the GSH consumption in the cells, since the metabolism of MnSOD generates hydrogen peroxide, one of the substrates of glutathione peroxide, an enzyme that uses glutathione for its reduction. But probably in our study, the contact of CHO-k1 cells with the extracts of NR latex membranes stabilized with ammonia didn't raise the levels of ROS in the cells enough to provoke lipid damage.

Therefore, it is possible to conclude based on the results found in this work that the ammonia present in the natural rubber (NR) latex membranes can cause stress in CHO-k1 cells, influencing the cell metabolic activity. In lower concentrations of ammonia $(0.25 \%$ and $0.5 \%)$ the cells were able to adapt to the stressful environmental, but in higher concentrations (2.0\%) this adaptive capacity was suppressed, leading the cells to death and being cytotoxic to the cell lineage used. It was also verified that the ammonia presented in the NR latex membranes enhanced the consumption of GSH in the cells exposed to the extracts of these membranes. From these results, it is possible to assure that the use of ammonia for Hevea brasiliensis latex stabilization, which could be used to produce membranes with biomedical application, has to be done with caution avoiding possible harmful effects to human health.

\section{ACKNOWLEDGEMENTS}

The authors greatfully acknowledge Fundação de Amparo à Pesquisa do Estado de São Paulo (FAPESP), Universidade Estadual Paulista "Júlio de Mesquita Filho" (UNESP) and Universidade do Oeste Paulista (UNOESTE) for supporting this study, and the Agência Paulista de 
Tecnologia dos Agronegócios (APTA) for the use of its facilities.

\section{CONFLICT OF INTEREST}

The authors declare that there are no conflicts of interest.

\section{REFERENCES}

1. Ferreira M, Mendonça RJ, Coutinho-Netto J, Mulato $M$. Angiogenic properties of natural rubber latex biomembranes and the serum fraction of Hevea brasiliensis. Braz J Physics. 2009;39:564-9.

DOI:

http://dx.doi.org/10.1590/S0103-

$\underline{97332009000500010}$

2. Rippel MM, Lee L-T, Leite CA, Galembeck F. Skim and cream natural rubber particles: colloidal properties, coalescence and film formation. J Colloid Interface Sci. 2003;268:330-40. DOI: http://dx.doi.org/10.1016/j.jcis.2003.07.046

3. Herculano RD, Silva $C P$, Ereno $C$, Guimarães SAC, Kinoshita A, Graeff CFdO. Natural rubber latex used as drug delivery system in guided bone regeneration (GBR). Materials Res. 2009;12:2536. DOI: http://dx.doi.org/10.1590/S151614392009000200023

4. Herculano RD, de Queiroz AAA, Kinoshita A, Oliveira ON, Graeff CF. On the release of metronidazole from natural rubber latex membranes. Materials Sci Engin. 2011;31:272-5. DOI:

http://dx.doi.org/10.1016/j.msec.2010.09.007

5. Guidelli EJ, Kinoshita A, Ramos AP, Baffa O. Silver nanoparticles delivery system based on natural rubber latex membranes. J Nanoparticle Res. 2013;15:1-9. DOI: http://dx.doi.org/10.1007/s11051-013-1536-2

6. Danna CS, Cavalcante DGSM, Gomes AS, Kerche-Silva LE, Yoshihara E, Osorio-Román IO, et al. Silver nanoparticles embedded in natural rubber films: Synthesis, characterization, and evaluation of in vitro toxicity. J Nanomaterials. 2016; Article ID 2368630:1-10. DOI: http://dx.doi.org/10.1155/2016/2368630

7. Valodkar M, Jadeja RN, Thounaojam MC, Devkar RV, Thakore S. In vitro toxicity study of plant latex capped silver nanoparticles in human lung carcinoma cells. Materials Sci Engin. 2011;31:1723-8.

DOI:

http://dx.doi.org/10.1016/j.msec.2011.08.001

8. Mrué F, Coutinho-Netto J, Ceneviva R, Lachat JJ, Thomazini JA, Tambelini H. Evaluation of the biocompatibility of a new biomembrane. Materials Res. 2004;7:277-83. DOI: http://dx.doi.org/10.1590/S151614392004000200010

9. Ho CC, Kondo T, Muramatsu N, Ohshima H. Surface structure of natural rubber latex particles from electrophoretic mobility data. J Colloid Interface Sci. 1996;178:442-5. DOI: http://dx.doi.org;10.1006/icis.1996.0139

10. Erickson RJ. An evaluation of mathematical models for the effects of $\mathrm{pH}$ and temperature on ammonia toxicity to aquatic organisms. Water Res. 1985;19:1047-58. DOI: http://dx.doi.org/10.1016/0043-1354(85)90375-6

11. Atanassanov $\mathrm{CL}$, Muller $\mathrm{CD}$, Dumont $\mathrm{S}$, Rebel $G$, Poindron $P$, Seiler N. Effect of ammonia on endocytosis and cytokine production by immportalized human microglia and astroglia cells. Neurochem Int. 1995;27:417-24. DOI: http://dx.doi.org/10.1016/0197-0186(95)00023-2

12. Murthy CR, Rama Rao KV, Bai G, Norenberg $M D$. Ammonia-induced production of free radicals in primary cultures of rat astrocytes. J Neurosci Res. 2001;66:282-8. DOI: http://dx.doi.org/10.1002/inr.1222

13. Almeida LM, Floriano JF, Ribeiro TP, Magno LN, da Mota LS, Peixoto $N$, et al. Hancornia speciosa latex for biomedical applications: physical and chemical properties, biocompatibility assessment and angiogenic activity. J Materials Sci: Materials Med. 2014;25:2153-62. DOI: http://dx.doi.org/10.1007/s10856-014-5255-8

14. Moura JML, Ferreira JF, Marques L, Holgado L, Graeff CFO, Kinoshita A. Comparison of the performance of natural latex membranes prepared with different procedures ad PTFE membrane in guided bone regeneration (GBR) in rabbits. J Materials Sci: Materials Med. 2014; 25:2111-20.

DOI: http://dx.doi.org/10.1007/s10856-014-5241-1 
15. Park B, Martins $P$, Harris C, Guest R, Whittingham $A$, Jenkinson $P$, Handley J. Initial in vitro screening approach to investigate the potential health and environmental hazards of EnviroxTM - a nanoparticulate cerium oxide diesel fuel additive. Particle Fibre Toxicol. 2007;4:12. DOI: http://dx.doi.org/10.1186/17438977-4-12

16. Van der Oost R, Beyer J, Vermeulen NPE. Fish bioaccumulation and biomarkers in environmental risk assessment: a review. Environm Toxicol Pharmacol. 2003:13: 57-149. DOI: $\quad$ http://dx.doi.org/10.1016/S13826689(02)00126-6

17. Mosmann T. Rapid colorimetric assay for cellular growth and survival: application to proliferation and cytotoxicity assays. J Immunol Meth. 1983;65:55-63. DOI: http://dx.doi.org/10.1016/0022-1759(83)90303-4

18. Ellman GL. Tissue sulfhydryl groups. Arch Biochem Biophys. 1959;82:70-7. DOI: http://dx.doi.org/10.1016/0003-9861(59)90090-6

19. Bradford MM. A rapid and sensitive method for the quantitatin of microgram quantities of protein utilizing the principle of protein-dye binding. Analyt Biochem. 1976;72:248-54. DOI: http://dx.doi.org/10.1016/0003-297(76)9027-3

20. Uchiyama M, Mihara $M$. Determination of malonaldehyde precursor in tissues by thiobarbituric acid test. Analyt Biochem. 1978;86:271-78.

DOI: http://dx.doi.org/10.1016/0003-2697(78)90342-1

21. Balabanian CACA, Coutinho-Netto J, LamanoCarvalho TL, Lacerda SA, Brentegani LG. Biocompatibility of natural latex implanted into dental alveolys of rats. J Oral Sci. 2006;48:201-5. DOI: http://dx.doi.org/10.2334/josnusd.48.201

22. Ereno C, Guimarães SAC, Pasetto $S$, Herculano $R D$, Silva CP, Graeff CFO, et al. Latex use as an occlusive membrane for guided bone regeneration. J Biomed Materials Res Part A. 2010;95A:932-9. DOI:

http://dx.doi.org/10.1002/jbm.a.32919

23. Floriano J, Mota L, Furtado E, Rossetto V, Graeff CO. Biocompatibility studies of natural rubber latex from different tree clones and collection methods. J Materials Sci: Materials Med. 2013;25:461-70. DOI: http://dx.doi.org/10.1007/s10856-013-5089-9

24. Andrade TAM, Iyer A, Dias PK, Foss NT, Garcia $\mathrm{SB}$, Coutinho-Netto J, et al. The inflammatory stimulus of a natural latex biomembrane improves healing in mice. Brazilian J Med Biol Res. 2011;44:966-1069. DOI:

http://dx.doi.org/10.1590/S0100$\underline{879 \times 2011007500116}$

25. Mendonça RJ, Maurício VB, Bortolli Teixeira L, Lachat JJ, Coutinho-Netto J. Increased vascular permeability, angiogenesis and wound healing induced by the serum of natural latex of the rubber tree Hevea brasiliensis. Phytother Res. 2010;24:764-8.

DOI:

http://dx.doi.org/10.1002/ptr.3043

26. Berridge MV, Herst PM, Tan AS. Tetrazolium dyes as tools in cell biology, new insights into their cellular reduction. Biotechnol Ann Rev. 2005;11:127-52.

DOI: http://dx.doi.org/10.1016/S1387-2656(05)11004$\underline{7}$

27. Kupcsik L. Estimation of cell number based on metabolic activity: The MTT reduction assay. Mammal Cell Viability. 2011;740:13-9. DOI: http://dx.doi.org/10.1007/978-1-61779-108-6 3

28. Martinelle K, Häggström L. Mechanisms of ammonia and ammonium ion toxicity in animal cells: Transport across cell membranes. J Biotechnol. 1993;30:339-50. DOI: http://dx.doi.org/10.1016/0168-1656(93)90148$\underline{\mathrm{G}}$

29. Zhang Q, Pi J, Woods CG, Jarabek AM, Clewell III, HJ, Andersen ME. Hormesis and adaptive cellular control systems. Dose-Response. 2008;6:196-208. DOI: http://dx.doi.org/10.2203/dose-response.07028.Zhang

30. Bobermin LD, Wartchow KM, Flores MP, Leite MC, Quincozes-Santos, Gonçalves, CA. Ammoniainduced oxidative damage in neurons is prevented by resveratrol and lipoic acid with participation of heme oxygenase 1 . Neurotoxicol. 2015;49:28-35.

DOI:

http://dx.doi.org/10.1016/j.neuro.2015.05.005 
31. Klejman $A$, Wegrzynowicz $M$, Szatmari $E$, Mioduszewska B, Hetman $M$, Albrecht J. Mechanisms of ammonia-induced cell death in rat cortical neurons: roles of NMDA receptors and glutathione. Neurochem Int. 2005;47:51-7. DOI:

http://dx.doi.org/10.1016/j.neuint.2005.04.006

32. Koga M, Serritella AV, Messmer MM, HayashiTakagi A, Hester LD, Snyder SH, et al. Glutathione is a physiologic reservoir of neuronal glutamate. Biochem Biophys Res Commun. 2011;409:596602.

DOI:

http://dx.doi.org/10.1016/j.bbrc.2011.04.087

33. Spanaki C, Plaitakis A. The role of glutamate dehydrogenase in mammalian ammonia metabolism. Neurotoxicity Res. 2012;21(1):11727. DOI: http://dx.doi.org/10.1007/s12640-011$\underline{9285-4}$

34. Davuluri G, Allawy A, Thapaliya S, Rennison $\mathrm{JH}$, Singh $\mathrm{D}$, Kumar $\mathrm{A}$, et al. Hyperammonemia induced skeletal muscle mitochondrial dysfunction results in cataplerosis and oxidative stress. J Physiol. 2016;594(24):7341-60. DOI: http://dx.doi.org/10.1113/JP272796 